\title{
The Relationship between HR Competencies and Organizational Performance in the Banking Sector in Nigeria
}

\author{
Choi Sang Long \\ Faculty of Business, Raffles University Iskandar, \\ Menara Kotaraya, Level 9, Jalan Trus, 80000 Johor Bahru, Johor, Malaysia \\ E-mail: cslong_1@yahoo.com
}

Goh Chin Fei

Faculty of Management, Universiti Teknologi Malaysia, Malaysia

Uti Charles Amechi

Faculty of Management, Universiti Teknologi Malaysia, Malaysia

Tan Owee Kowang

Faculty of Management, Universiti Teknologi Malaysia, Malaysia

Received: Jan. 17, 2018 Accepted: Jan. 30, 2018 Online published: Feb. 2, 2018

doi:10.5296/ijhrs.v8i1.12459 URL: https://doi.org/10.5296//ijhrs.v8i1.12459

\begin{abstract}
This study investigated the relationship between HR competencies and organizational performance by adapting the Ulrich HR Role Model. The study also examined HR competencies such as strategic positioner, credible activist, capability builder, change champion, HR innovator/integrator, technology proponent and project facilitator. The research is based on $215 \mathrm{HR}$ professionals from 20 consolidated banks located in South-West Nigeria. A quantitative approach was used for the analysis. The findings revealed that all HR competencies also have significant correlation with organizational performance. Furthermore, competency such as strategic positioner and technology proponent provide most impact to
\end{abstract}


organizational performance.

Keywords: HR competencies, organizational performance, technology proponent, strategic positioner, credible activist

\section{Introduction}

Almamun (2009) described human resources (HR) to be the energies; the skills, the talents and the knowledge which people have that can be used for the production of goods or in rendering quality service. He further added that human capital; structural capital and intellectual capital concepts were similar to other types of assets. Som (2008) also defined human resource management to be a carefully designed combination of practices that gear towards the development of organizational value and thus superior performance outcomes. Nonetheless, Adeniji et al., (2013) stresses that in the last two epochs, studies have revealed that HRM has the capability of becoming the most critical organizational performance determinant in view of researchers (Paauwe \& Boselie, 2005; Wright, Snell \& Dyer, 2005; Som, 2008) evidences that connect HRM practices with corporate performance.

However, a review of extant literature (Kim \& Sung-Choon, 2011; Bhatnagar \& Sharma, 2005; Clark and Cooling, 2005; Christiansen, 2008; Scotts, 2008; Aitchison, 2007; Long \& Wan Khairuzzaman, 2008; Pietersen \& Engelbrecht, 2005) on HR competencies and organizational performance revealed that various studies have been carried out on the required competencies of HR professionals as well as the expected strategic partner role of the HR professionals. Therefore, the need for human resource professionals to become intricate in human resource strategic management (HRM), contributing to organizations competitive advantage, becoming true strategic partners that add value as well as shifting from the transactional functions to transformational role has been the critical issues of debate with the view of making HR truly strategic as there have been serious deliberations regarding the contributions of HR to organizational performance lately (Ulrich et al., 2008). Nevertheless, the deliberations arise as a result of incapability of the human resource function to validate its palpable significance, as well as justify its privation at the strategic level. The management practice where human resource task is devolved downwards from the corporate central units to the business unit-levels and further downward to the line management has generated undue restructuring of the human resource tasks.

Today, notwithstanding the enhanced interest in the development of the HR function as validated by several researches in the area (Cole, Lemmon, \& Wang, 2009; Bourne \& Franco-Santos, 2010), the call for transformation, collective capriciousness, and the distortion of precincts in the business sphere has pointed the attention of organizations towards the attainment of strategic prominence which has consequently enhanced the drive for a new strategic role for HR professionals. Unfortunately, only a few numbers of empirical researches have been carried out on the new competencies that organizations expect HR professionals to demonstrate (Ulrich et al., 2012).

However, after the review of previous literature on this subject, it was observed that research addressing jointly the conceptual relationship between human resource competencies and 
organizational performance has been overlooked in literature especially in the African continent, hence it has triggered this study. Therefore, to cover this gap in the literature, this current study investigates the variable of HR competencies and organizational performance. More so, to strengthen the requisite HR competencies that will ensure HR professionals add value to their organizations adequately, it is also observed from literature that skills in project facilitation is a necessity for HR professionals, as such this study modifies the Ulrich et al (2012) HRCS model by introducing an additional competency called the project facilitator.

\section{Literature Review}

Ulrich et al (2012) in their current human resource competency survey (HRCS) identifies six vital competency spheres that every HR professional must validate in order to influence business performance:

- $\quad$ Strategic Positioner

- $\quad$ Credible Activist

- $\quad$ Capability Builder

- Change Champion

- $\quad$ HR Innovator/Integrator

- Technology Proponent

This study adds the project facilitator competency to the above list. This competency has become imperative for HR and the consolidated banking sector in Nigeria owing to the fact that new projects are being developed continuously because of the dynamical competition in the sector (Mugarvin, 2012). In order to execute these projects adequately, on time and within budget, HR professionals need to know and acquire the techniques of project facilitation, which will help develop the skills of project facilitators and project team members in the consolidated banking sector (Edmonds, 2010). The competency of project facilitator will enable HR professional to schedule, cost, quality control, ensure customer satisfaction, planning, control and risk management (Clark and Cooling, 2005). Consequently, these competencies will ensure enhanced productivity in the massive recruitment, training, benefit, compensation and payroll processes in the consolidated banking sector in Nigeria (Scotts, 2008).

\subsection{Competencies of HR Professionals}

\subsubsection{Strategic Positioner}

According to Ulrich et al., (2012), the concept of human resources describes that HR professionals require to become strategic partners in the organization. Human resource professionals, who are unable to read and interpret financial statements; make strategic contributions; recognize and attend to external stakeholders; and predict as well as respond to business drifts, will be inept to providing requisite input to business discussions. 


\subsubsection{Credible Activist}

Human resource professional's credibility is expected to be to their colleagues and line managers. It is imperative that HR professionals fulfill their promises and deliver results, establishing an unswerving track record. Additionally, the ability to work acceptably with others through the establishment of cordial relationship is crucial in developing the knack for effective collaboration. Furthermore, HR professionals ought to possess effective and efficient writing as well as oral communication skills (Boselie \& Paauwe 2004).

\subsubsection{Capability Builder}

Ulrich et al., (2012) posit that emergent capabilities of successful organizations are the creation of organizations where the workforces can discover value and drive at work. They conclude by saying that HR professionals have the capacity to support line managers generate value so that the innate standards of the employees can reflect the capability of the organization.

\subsubsection{Change Champion}

Selmer and Chiu (2004) found in their study that the top priority organization's CEO does expect their HR professionals to be competent and have the capacity to play a change agent role. HR professionals may not see the importance of being a change agent compared to their CEO's. This further support the notion that HR professionals now are still unaware of the competencies needed to be the change champions they ought to be, which will enable them contribute strategically to their organizations. The impetus of organizational change and growth originates from diverse populations of people and resources. Identifying HR competencies needed to adapt and effect competitive change within 21st-century organizations may rest in the fundamental role of change management, in addition to organizational leaders being acutely aware of possessing the ability to predict change and adjust to that change.

\subsubsection{Human Resource Innovator and Integrator}

Ulrich et al., (2007) noted that organizational design concentrates on how an organization embeds capability into the structure, processes, and policies that shape how that organization works. HR professionals ensure that the organization's means of talent management and organizational capabilities are aligned with customer requirements and strategy, integrated with each other, and are working effectively and efficiently. They added that HR is not just about the two of them together, stating that good talent without a supporting organization will not be sustained, and a good organization will not deliver efficient results without talented individuals that possess the right competencies in critical roles (Ulrich et al., 2007).

\subsubsection{Technology Proponent}

A comprehensive knowledge of the contemporary technologies employed in present day HR practice will ensure an improved organizational personality outside the business and will improve social interactions inside the company. It has become imperative for HR to begin to access, carry out analysis, advocacy, as well as aligning modern technology in order to 
enhance information, efficiency as well as relationships within the company as the technology proponent competency becomes critical (Ulrich et al., 2012).

\subsubsection{Project Facilitator}

An efficient project facilitator is involved from the beginning of the project to the very end, and must have an enduring perception if the project must excel. He must be motivational, directing and controlling the team effectively to enable them achieve set targets. Peradventure the project fails to realize its set objectives, the project facilitator takes responsibility for the failure, as such, it is imperative that HR professionals are adequately equipped with requisite competencies to enable them face the challenges of managing projects efficiently (Martins, 2007). The special capabilities and requirements of a project facilitator equally entails specialist training that is a product of methodology. It involves the provision of a framework that covers a myriad of requisite disciplines that brings about efficient project management practices in HR.

\subsection{Relationship Existing between HR Competencies and Organizational Performance}

Christiansen and Higgs (2008) argued that as HR professionals increase their proficiency levels in business-related HR competencies and professional HR competencies, their performance outputs would generally be expected to improve. They further submitted that organization whose HR professionals have high proficiency levels are organizations that would be expected to have superior organizational performance. However, this is not always the case as an individual may possess the required business knowledge, management and technical skills, abilities to change behaviors, but may be performing at a lower level than expected due to various factors such as; personal problems, lack of focus, job dissatisfaction, negative reaction to organizational change, lack of organizational resources, and more. Christiansen and Higgs (2008) reiterated that HR professionals are rated on performance in relation to how well they have accomplished the tasks set out in their organization's performance plans. Performance plans establish specific tasks and expectations for various positions and employee grade levels and this is the basis for performance evaluation that enhances organizational performance.

Furthermore, indications from the data reveal that HR competencies such as strategic architect shared by HR executives, line and senior managers, as enablers of alignment, contribute to organizational performance (Christiansen \& Higgs, 2008), which is similar to the capability builder competency domain of the HRCS 2012 study conducted by Ulrich et al. (2012).

Liu, Fu, Wang and Fang (2014), in their study argue that human resources remains the critical resources that ensures organizations competitive edge. They argue that HR professionals play an essential role in the organization's competition, as well as possessing the potentials to increase the value of the organization by the promotion of their competencies. They further stressed that both within the academia and in organizational management practices, the improvement of employees' competency has become an imperative norm. However, different competencies are required in different industries, 
organizations and position, therefore, it has become necessary to carry out a detailed study on competencies required for specific industries and positions.

Levenson (2005) in his study argued that the demonstration of an uninterrupted relationship between HR professional competencies and organisational performance is quite a difficult obstacle to resolving the deliberation over the proper utilization of HR professional competencies; he therefore provided fresh evidences from an illustration on the mechanisms through which compensating HR professional competencies is capable of impacting the behaviour of executives' in a method that eventually influences organizational performance. Subsequently, in collaborating Levenson's (2005) view, Christiansen and Higgs (2008) argued that while several researchers aver that HR professional competencies has the capacity to offer organizations competitive edge, it is usually a challenge identifying which of the competencies really does. They further emphasized that conducting a test for such affirmations could be an intricate deviation in the culture of the organization, knowing that culture is a significant factor that is inimitable.

However, Russell (2001) had earlier shown a nexus between business-related competencies employed when selecting general managers and the successive performance of that unit. But Levenson, Van der Stede, and Cohen (2005) later discovered a nexus between business-related HR professional competencies employed when rewarding line managers as well as unit performance of organizations. Consequently, Wright, Dunford, and Snell (2001) emphasized that HR practices have the capacity to enhance organizational performance as well as becoming a source of sustained competitive advantage. The existing competition in the global market is tumultuous, and it encumbers the HR function in its endeavors to assist management create and maintain competitive advantage they argued. The need for HR professionals to master the necessary HR competencies such as; strategic positioner, credible activist, capability builder, change champion, HR innovator and integrator, and technology proponent, if they must function effectively has become imperative, and that mastery only emanates having a knowledge of the concepts, logic, language, research skills, and HR practices (Brockbank et al., 2002, Ulrich al., 2012). Additionally, mastery of the ability to apply the acquired requisite experience in a particular business situation is what brings the mastery that enhances organizational performance.

Lawler and Mohrman (2003) also argued that the need for HR professionals to become effective strategic business partners has become crucial. Ulrich and Brockbank (2001) further stressed the need for HR professionals to undergo the change process from strategic business partners to wide-ranging providers to the success of the organization. According to previous researches by (Boselie \& Paauwe, 2004; Ramlall, 2006; Long \& Wan Khariruzzaaman, 2008), there is a positive relationship between certain HR competencies such as; business knowledge, personal credibility, strategic contribution, HR delivery, HR technology and strategic HR performance and organizational performance. In the views of Losey (1999), a collection of HR professionals looking forward to the prospects of transforming human capital strategy into an enduring competitive advantage is emerging. $\mathrm{He}$ reiterated that the call to action in the human resource profession was initially made in the 1990s. Like never before, today, organizations are seeking improved ingenuity and 
efficiency in possessing the requisite competencies that will enable the expected result of increased competitive advantage. The HR competencies itemized by these researchers are similar to the latest HR competencies; strategic positioner, credible activist, capability builder, and HR innovator/integrator developed by Ulrich et al., (2012).

Lee et al., (2011) in their study, however, emphasized that HR's challenge in taking up critical roles at the management table was based on the increasing expectation of its contribution to the organization. This challenge is becoming enormous since the necessities are not merely fluctuating, but obviously developing. The HR task is presently depended upon for expertise in the design of organizational structures and for the management of core changes that will increase competitiveness, added to their conventional HR masteries. These expected results need competency in the area of strategic contribution and the capacity to provide HR functions effectively to enhance organizational performance.

The fact that people are the key assets that determines the advancement process of organizations, and thus the significance of the knowledge, skills, attitudes and behaviors of these people for the good of the organization is not debatable. However, Kovach, Hughes, Fagan, \& Maggitti (2002) argues that organizations do not possess absolute control over this asset, yet they can utilize certain contraptions and techniques to wield some critical impact over the way they perform regarding the attainment of the set goals of the organization. Kovach et al., (2002) further argued that the concept of Electronic Human Resource Management known as e-HRM, which is the adoption of technology in the delivery of HR practices due to the global digital revolution, is a perfect tool employable by organizations for the manipulation of the performance and behavior of people on whom they rely on for the success of their organizations. Therefore, the need for HR professionals to acquire competencies that will make them technology proponents is inevitable. Consequently, Ulrich et al., (2012) emphasized that HR information systems have been applied in the enhancement of efficient HR processes, in the areas of payroll processing, benefits, healthcare costs, record keeping, and other administrative functions. They stressed that in the latest competency survey, they observed a dramatic change in the implications of technology for HR professionals, stating that high performing HR professionals are now applying social networking technology in helping people stay connected with each other within the organization and their customers. They further emphasized, that with the technology proponent competency, HR professionals are beginning to increase their role in management information, which includes identifying the information that require attention, bundling such information's to usable knowledge, leveraging such knowledge into critical decisions that ensure competitive edge for the organization.

Ulrich et al., (2008) argued that HR professionals as change stewards now called change champions in the latest competency survey, facilitate changes in two ways, first by helping enshrine the culture of the organization and secondly, they create an atmosphere of discipline that initiates change within the organization.

Harold (2003) opines that the acquisition of project management competencies by HR professionals enhances their efficiency and expertise in successful project execution, adding 
that the ability to complete such HR related projects within record time and within budget helps organizations gain a competitive edge in the global market. Hashim and Chileshe (2012) argued that the ability to effectively manage multiple projects is an emerging competency that is critically significant for HR professionals if they must add value to their organizations. They further argue that the number of HR related projects generated to ensure sustained competitive advantage for organizations through its HR is on the increase.

Clark and Cooling (2005) posits that project management, which is an approach of work organization, obligation and regulation is not perceived to be relevant by HR professionals, however, it is a critical role that enables and supports project - based organizations, helping them create effective team work, patterns of competence and management development that help organizations gain competitive advantage. Collaborating the views of Clark and Cooling (2005), Mugavin (2012) posits that the development of efficient project management competency enhances other essential HR competencies that HR professionals require to support their organizations in achieving set goals. Mugavin (2012) further argued that competency in project management helps HR professionals to achieve crucial results that meet the team, department and strategic requirements, complete projects in record time, within budget as well as meet quality standards. The researcher stressed that project management competency enables HR professionals to curtail the time of improvement, by discovering methods of providing their objectives within a realistic time frame that enable organizations prevent the business risk that gives them the competitive edge.

Advocates of competency might take a glance at all the effects and resolve that HR competencies are precisely playing their role as envisioned. Nevertheless, it is believed that there are various operational matters needed to be resolved before arriving at such conclusions. Firstly, these studies are limited, in relation to the number of organizations that employ HR competencies. The available empirical evidence supports the conclusion, which states that HR competencies have the capability of improving an organization's performance as in the cases reviewed. However, the evidence did not support nor disprove the assertion that HR competencies actually improve organizational performance the way they are characteristically executed in organizations.

However, this current study intends to ratify the above assertion concerning the relationship existing between HR competencies and organizational performance in the consolidated banking sector in Nigeria.

Therefore, the hypothesis states that:

H1: HR competencies comprising strategic positioner, credible activist, capability builder, change champion, HR innovator and integrator, technology proponent and project facilitator are significantly related to organizational performance.

\section{Research Methods}

\subsection{Research Design}

This research employed the quantitative method of research in the processing of the data 
collected on the competencies of HR professionals as it relates to organizational performance. The study engaged the use of questionnaires that was developed for the purposes of data collection.

Consequently, the hypothesis developed was tested for validation, while the variables examined in the research comprises of the HR competencies and organizational performance. With such timely information gathered, the researcher hopes to increase the level of understanding linked to HR professional competencies to organizational performance. It also highlights the strategic partner role. Also, the existing relationship between these variables is considered and finally, the data gathered were analyzed using the Statistical Package for the Social Sciences (SPSS) version 20 software. Most related studies on HR strategic partner roles and competencies have utilized quantitative approaches as the selected research strategy.

A comprehensive list of all the consolidated banks in Nigeria serves as the sampling frame in this research. The organizational size of the banks in the sample frame, measured in a number of HR professionals, range from 20 to 35. The age of the banks spanned from 5 to over a 100 years. The annual revenues of the banks varied from N70 million to less than N500 million. All the respondents are employed in consolidated banks in Nigeria. The banks were investigated in this study based on their vibrancy, organization, stability and relatively large size. The expectations of HR are significant in the consolidated banking sector. Activities such as organizational restructuring, mergers, international forays through expansion and acquisitions and upgrading of technology in the consolidated banking sector in Nigeria makes an HR department critical and vivacious. This is another reason why this industry is selected for this research as all the consolidated banks in Nigeria engage in HR operations.

\subsection{Sampling Technique}

For this research to acquire the needed information, data were gathered from the consolidated banking sector in Nigeria. Understanding that the issues examined in this study and the methodology employed required a fairly large number of respondents to ensure an accurate statistical analysis in the investigation, as the sample was chosen on the basis of cluster sampling. According to Sekaran (2003), area sampling comprises geographical groups; which entails the research of a population within an area - city, state, region, identifiable geographic area. It might be specific boundaries in a vicinity. Hence, cluster sampling is described as a method of group sampling in a region. The main reason for employing the cluster sampling is to increase the efficiency of survey administration by reducing cost. Secondly, the generation of a sample frame is usually readily available at cluster level. It is also suitable for survey of institutions.

\subsection{Population and Sample Size}

This study employs a sample size consisting of the total population of HR professionals within the consolidated banking sector in Nigeria. The entire respondents are HR professionals who work for the consolidated banks located in South-West Nigeria. These banks were selected because of their vibrancy, organization and comparatively enormous 
size. The list containing the number of banks was obtained from the Central Bank of Nigeria (CBN) directory of consolidated banks in Nigeria, 2012.

The population of the HR professionals in the 20 consolidated banks in Nigeria as obtained from the CBN directory is about 600. This study, therefore employed the sampling method for research activities developed by Krejcie and Morgan (1970). In line with the above sampling size table by Krejcie and Mogan (1970), the questionnaire was forwarded to 240 respondents, which comprises of HR professionals in the 20 consolidated banks located in the South-West Nigeria, on an average of twelve (12) questionnaires per bank, with an expectation that adequate responses will be retrieved for analysis.

\subsection{Research Instrument on HR Competencies}

Quantitative methodology is employed as a data collection tool for in this part of the study, the concept of the research tool is drawn from the six competency areas with 20 competency issues classified in the latest human resource competency survey (HRCS) conducted by Ulrich et al., (2012). The project facilitator domain is an addition to this research, and that amounts to 24 competency factors, which exist in the seven competency areas being investigated. This is the first part of the instrument.

The second part of the instrument is based on Ulrich's HR Role Model, as developed by Ulrich and Brockbank (2005). It is used for testing the theoretical model for the strategic partner role, which is a critical HR role discussed in Conner and Ulrich (1996), Ulrich (1997) and Ulrich and Brockbank (2005). The research instrument employed in this study is the survey design, aimed at determining the existence and extent to which strategic partner role highlighted by Ulrich and Brockbank (2005) is practiced.

The third part of this research instrument was used to measure organizational performance. This part of the instrument is an adaptation from studies previously done by Richard et al, (2009) and Bourne and Franco-Santos (2010) on the measurement of organizational performance. Organizational performance is measured by self-report rating of the participants regarding the pointers of financial and operational performance, sustenance of profits, and employee turnover and growth prospect for staff.

A self-reported rating system of organizational performance was utilized in this study for the following reasons; firstly, because skewed performance measurement is broadly employed in strategic studies (Lahteenmaki, Storey, \& Vanhala, 1998, Golden, 1992) and several studies indicate that a significant correlation exists amid skewed responses and fair measures (Robinson \& Pearce, 1988). Datta (1991) claims that managers are poised to state the position of performance clearly as against other processes and approaches. Secondly, it ensures that accountability among various organizations such as small, medium-sized and large organizations were practiced. Furthermore, organizations are usually, reluctant in rendering their financial details, and the financial data that are normally published can only be obtained from large organizations that operate at the corporate level, which is why many comparative studies trust on the self-reported rating about organizational performance exclusively or jointly with unprejudiced financial pointers (Lahteenmaki et al. 1988, Richard 
et al., 2009, Chandra, 2009).

\section{Data Analysis and Discussion of Findings}

\subsection{Tests of Normality}

The test of normality is determined by the shape of the distribution and the normality describes the distribution of the data. For a data set to be normally distributed, the mean is expected to be at (0) and standard deviation at (1) (Groebner and Shannon, 1990; Lewis-Beck et al., 2004), this plays a significant role in the underlying assumptions for multivariate data analysis (Hair et al., 2006; Paschke, 2009). This study performed the Kolmogrov-Smirnov and Shapiro-Wilk statistics to test the normalities of the data used in the study. A total of nine (9) variables were utilized, and breakdown of the variables and their number of items includes: strategic positioner (3 items), credible activist (4 items), credibility builder (3 items), change champion ( 2 items), HR innovator/integrator ( 5 items), technology proponent (3 items), project facilitator (4 items), strategic partner role (10 items) and organizational performance (10 items). The Kolmogorov Smirnov-Wilk statistics result is shown in Table 1. Table 1 shows the results of the Kolmogorov-Smirnov statistics with Lilliefors significance level that tests the normality of variables. This statistic test states that if the significance level is greater than .05 , that shows that normality has been attained. However, the Shapiro-Wilk statistical test is usually calculated when the sample size is below one hundred. Therefore, since the sample size of this study is 215 excluding outliers which is above one hundred, the statistical value for Kolmogorov-Smirnov approach is implemented. Consequently, a critical look at the table 4.3 reveals that all the variables attained normality in the test as they are all greater than .05 significance level.

Table 1. Tests of Normality

\begin{tabular}{lcccccc}
\hline \multirow{2}{*}{ VARIABLES } & \multicolumn{3}{c}{ Kolmogrov-Smirnov } & \multicolumn{3}{c}{ Shapiro-Wilk } \\
\cline { 2 - 7 } & Statistics & df & Sig. & Statistics & df & \multicolumn{1}{c}{ Sig. } \\
\cline { 2 - 7 } Strategic Positioner & .161 & 12 & .200 & .885 & 12 & .101 \\
Credible Activist & .287 & 5 & .200 & .914 & 5 & .490 \\
Credibility Builder & .168 & 8 & .200 & .965 & 8 & .859 \\
Change Champion & .221 & 10 & .200 & .922 & 10 & .544 \\
HR Innovator/Integrator & .124 & 21 & .200 & .968 & 21 & .699 \\
Technology Proponent & .172 & 18 & .170 & .943 & 18 & .323 \\
Project Facilitator & .169 & 17 & .200 & .912 & 17 & .109 \\
Strategic Partner Role & .166 & 18 & .200 & .89 & 18 & .046 \\
Organizational Performance & .145 & 7 & .200 & 959 & 7 & .809 \\
\hline
\end{tabular}

*. This is a lower bound of the true significance. a. Lilliefors Significance Correction

\subsection{HR Competencies Level of HR Professionals Based on Each Domain}

The first objective of this research is to identify the level of human resource competencies among HR professionals in the consolidated banking sector in Nigeria. The mean scores for each variable of the human resource competencies are shown in Table 2 as they reflect the level of competencies possessed by HR professionals in rank. 
Table 2. Mean Scores of HR professionals Human Resource Competencies Level

\begin{tabular}{ccccc}
\hline & N & Mean & $\begin{array}{c}\text { Standard } \\
\text { Deviation }\end{array}$ & Rank \\
\hline Strategic Positioner & 215 & 3.33 & 1.84 & 1 \\
Credible Activist & 215 & 2.44 & 2.63 & 6 \\
Credibility Builder & 215 & 2.67 & 2.24 & 5 \\
Change Champion & 215 & 3.25 & 1.33 & 2 \\
HR Innovator/Integrator & 215 & 2.20 & 2.25 & 7 \\
Technology Proponent & 215 & 2.84 & 2.13 & 3 \\
Project Facilitator & 215 & 2.82 & 3.87 & 4 \\
\hline
\end{tabular}

As shown in Table 2, the HR professionals in the study responded by identifying the level of HR competencies they possess, the results show that the level of HR competencies they possess is highly significant in the areas of strategic positioner and change champion as the competencies have the highest rankings, with the mean scores of 3.33 and 3.25 respectively, while the HR Innovator / Integrator competency had the lowest mean score of 2.20.

These findings therefore contradicts the results of the study conducted by Ulrich and associates in the sixth round of the Human Resource Competency Survey (HRSC) in 2012, as presented by Brockbank et al., (2012), which emphasizes that human resource professionals work adequately as credible activists, stating that the human resource professionals are more efficient at the building of credibility through the establishment of relationships that ensure trust, communication of vital HR and business related issues, that spur their ability to advocate enthusiastically intuitive opinions capable of driving the business. But this study conducted in the consolidated banking sector in Nigeria reveals otherwise, it emphasizes that HR professionals function appropriately as strategic positioner and change champion. This may be due to the pressure from the acquisition and merger exercise that is inevitable process of consolidation in the banking sectors. According to Brockbank and Ulrich, (2003), if HR professionals are unable to expedite change management practices, as well as adjust to acquiring innovative transformation initiatives that are sustainable, it will be problematic for them to work in environments where they are expected to make swift and crucial decisions that will ensure the alignment of resources with the desired organizational changes.

Consequently, the need for HR professionals to improve trust thresholds in their relationship with clients, which will reenact confidence is vital. Findings from this study, however, revealed a significant development for HR in the Nigerian consolidated banking sector, since the strategic positioner and change champion competencies are crucial in HR strategic partnership. These competencies are vital if HR must be invited to the management table as they are expected to add value to the organization. Consequently, results from the study showed that HR innovator/integrator competency had the lowest score. HR innovator/integrator underpins the rationality that HR practices should integrate towards the creation and sustenance of major organizational capabilities that will impact business performance significantly. However, based on the result above, this is obviously lacking in the banking sector in Nigeria. This is also an indication that the HR professionals in the Nigerian consolidated banking sector lack adequate competencies in the areas of optimizing the human capital through the workforce planning and analysis, development of talent, 
shaping of organizations and the processes of communication and building a leadership brand.

Therefore, based on the result of this study, it reveals that the HR professionals in the Nigerian banking sector are yet to master or gain adequate competence as $\mathrm{HR}$ innovator/integrator, which will also impede the level of strategic partner role they play in this regard in their organizations.

\subsection{Relationship between Human Resource Competencies and Organizational Performance}

Table 3 reveals that all the seven (7) human resource competencies of HR professionals investigated in the study have significant correlation with organizational performance. Utilizing the Pearson Correlation Coefficient, the results show correlation values at .298, $.781,152, .245, .363, .897$, and 584 respectively. This results supported the below hypothesis;-

H1: There is a significant relationship between human resource competencies and organizational performance in the consolidated banking sector in Nigeria.

This results reveals that all the human resource competency factors are significantly correlated with the organizational performance. The result, therefore, fully supports an earlier study by Ulrich et al., (2012), that pointed out that the domain of strategic positioner, credible activist, credibility builder, change champion, HR innovator/integrator and technology proponent positively correlate with firm performance.

Table 3. Relationships Between HR Competencies and Organizational Performance

\begin{tabular}{lc}
\hline $\begin{array}{c}\text { Pearson Correlation } \\
\text { Coefficient }\end{array}$ & Organizational Performance \\
\hline Strategic Positioner & $.298^{* *}$ \\
Credible Activist & $.781^{* *}$ \\
Credibility Builder & $.152^{*}$ \\
Change Champion & $.245^{* *}$ \\
HR Innovator/Integrator & $.363^{* *}$ \\
Technology Proponent & $.897^{* *}$ \\
Project Facilitator & $.584^{* *}$ \\
\hline
\end{tabular}

**. Correlation is significant at the 0.01 level (2-tailed).

*. Correlation is significant at the 0.05 level (2-tailed).

The contributions of each of the HR competency domains to organizational performance were analyzed, employing a multiple regression analysis in testing the variables. Results from the analysis are stated in Tables 4. 
Table 4. Multiple Regression Analysis for HR Competencies on Organizational Performance

\begin{tabular}{|c|c|c|c|c|c|c|}
\hline \multirow[t]{2}{*}{$\begin{array}{c}\text { Independent } \\
\text { Variables }\end{array}$} & \multirow[t]{2}{*}{ Beta } & \multirow[t]{2}{*}{ Sig } & \multirow{2}{*}{$\begin{array}{c}\mathbf{R} \\
.992\end{array}$} & \multirow{2}{*}{$\begin{array}{c}\begin{array}{c}\text { Adjusted } \\
\text { R Sq }\end{array} \\
.984\end{array}$} & \multicolumn{2}{|c|}{$\begin{array}{c}\text { Collinearity } \\
\text { Statistics }\end{array}$} \\
\hline & & & & & Tolerance & VIF \\
\hline Strategic Positioner & .401 & .000 & & & .107 & 9.317 \\
\hline Credible Activist & .086 & .000 & & & .251 & 3.981 \\
\hline Credibility Builder & .031 & .002 & & & .793 & 1.261 \\
\hline Change Champion & -.015 & .599 & & & .102 & 9.828 \\
\hline HR Innovator & .073 & .000 & & & .612 & 1.634 \\
\hline Technology Proponent & .860 & .000 & & & .274 & 3.654 \\
\hline Project Facilitator & -.003 & .767 & & & .586 & 1.708 \\
\hline
\end{tabular}

Dependent Variable: Organizational Performance

Table 4 which addressed the contribution of HR competencies to organizational performance, shows the beta value which reveals that, among all the HR competencies, the one with the highest contribution to organizational performance is the technology proponent and strategic positioner. This result leads us to the conclusion that the HR department in the consolidated banking sector in Nigeria needs to focus more on the technology proponent and strategic positioner competencies to ensure the delivery of prime value to their organization. In addition, Ulrich et al (2012) stressed that these two competencies are relevant in today's business milieu.

This result is supported by the research of Kovach et al., (2002) which examined the concept of Electronic Human Resource Management known as eHRM, which is the adoption of technology in the delivery of HR practices due to the global digital revolution, which is a perfect tool employable by organizations for the manipulation of the performance and behavior of people on whom they rely on for the success of their organizations. They further opine that the need for HR professionals to acquire competencies that will make them technology proponents is inevitable.

The findings of this research are also supported by the study of Mukherjee (2001), which argue that HR professionals need the capability to impact technology for the practice of HR, and utilize e-HR or internet-based straits in delivering value to organizations. The researcher also argues that the speed at which technology and innovations are being developed is on the increase.

Consequently, Table 4 is supported by Ulrich et al., (2012), which also emphasized that the application of HR information systems has been in effect in the enhancement of efficient HR processes, with regards to payroll processing, benefits, healthcare costs, record keeping, and various administrative functions. They stressed that in the latest competency survey, they observed a vivid transformation in the effects of technology on the HR professionals, stating that veteran human resource professionals have began utilizing social interacting technology in helping people to be in contact with one another within the organization and their customers. They further emphasized, that with the technology proponent competency, HR 
professionals are beginning to increase their role in managing information, which comprises the identification of information requiring attention, hustling such information's to functional knowledge, leveraging such understanding into critical conclusions that ensure a competitive edge for the organization. In view of the result in Table 4, this study concludes that it is necessary for human resource to devote their attention on their technology proponent and strategic positioner skills to be able to make a meaningful impact in their organizations.

\section{Implications and Limitation of Study}

This study points out that HR professionals in the consolidated banking sector in Nigeria have traditionally functioned as support people in the organizations, however, new findings emerged from this study showing that HR professionals are gradually becoming strategic partners, but yet lack the confidence of top management to adequately allow them to fully participate at the management table. This research reveals that the HR professionals are deficient in certain competencies especially the competency of HR innovator / integrator. Organization should provide resources for the improvement of HR professional competencies in the identified areas of inefficiency, such as shaping the HR profession, aligning strategy, capability, developing talent, driving performance and building a leadership brand. Without this competency, it will be an uphill task for HR professionals to ensure of a positive involvement in an organization and these are the most susceptible capacities of HR professionals in the consolidated banking sector in Nigeria.

This research comprises of two hundred and fifteen (215) respondents, excluding outliers drawn from the consolidated banking sector, located in the South West, Nigeria. Therefore, it is impossible to generalize the findings to relate to the situation of all the human resource professionals in Nigeria. Though, the findings of this study cannot be replicated in the general HR competencies of HR professionals in Nigeria, yet it could be an exploratory research that is capable of being extended in future. HR professionals from other industries in Nigeria can be considered for future study.

\section{Conclusion}

This study measured the impact of HR competencies on organizational performance in the consolidated banking sector in Nigeria. The findings, however, reveal that indeed the most of the HR competencies contribute to organizational performance. Two most significant competencies are strategic positioners and technology proponent are most critical in improving organizational performance. The study also demonstrates that HR professionals in the consolidated banking sector in Nigeria are deficient in certain HR competencies especially in the competency of HR innovator / integrator.

\section{References}

Adeniji, A. A., Osibanjo, O. A., \& Abiodun, A. J. (2013). Organizational Change and Human Resource Management Interventions: An Investigation of the Nigerian Banking Industry. Serbian Journal of Management, 8(2), 1-16.

Aitchison, D. (2007). HR Transformation: Myth or Reality. HROA Europe and Sharedpertise 
Forums in Association with TPI. Survey reports January 2007.

Almamun, S. A. (2009). Human Resource Accounting (HRA) Disclosure of Bangladehi Companies and Its Association with Corporate Characteristics, BRAC University Journal, VI (1), 35-43.

Bhatnagar, J., \& Sharma, A. (2005). The Indian Perspective of Strategic HR Roles and Organisational Learning Capacity. International Journal of Human Resource Management, 16(9), 1711-1739. https://doi.org/10.1080/09585190500239424

Boselie, P., \& Paauwe, J. (2004). Human Resource Function Competencies in Europe Companies. Personnel Review, 34(5), 550-566. https://doi.org/10.1108/00483480510612512

Bourne, M., \& Franco, S. M. (2010). Investors in People, Managerial Capabilities and Performance. A Study Conducted by the Centre for Business Performance. Cranfield School of Management. Cranfield University.

Brockbank, W., \& Ulrich, D. (2003). Competencies for the New HR: Society for Human Resource Management, University of Michigan Business School, Global Consulting Alliance.

Brockbank, W., Sioli, A., \& Ulrich, D. (2002). So we are at the table! Now what?, working paper, University of Michigan Business School, Ann Arbor, ML, Retrieved July 19, 2013 from World Wide Web: http://webuser.bus.umich.edu/Programs/hrcs/res_NowWhat.htm

Chandra, N. (2009). Performance Measures: An Application of Economic Value Added. International Journal of Business and Management, 4(7), 739-752.

Christiansen, L. C., \& Higgs, M. (2008). Do HR Competencies Enable Organizations To Perform More Effectively? An Empirical Study of HR Competencies and Organizational Performance in Danish Companies. The Bristish Academy of Management Conference.

Clark, I., \& Cooling T. (2005). The Management of Human Resources in Project Management-led Organizations. Personnel Review, 34(2), 178-191. https://doi.org/10.1108/00483480510579411

Coles, J. L., Lemmon, M. L., \& Wang, Y. A. (2009). The Joint Determinants of Managerial Ownership, Board Independence, and Firm Performance. AFA Annual Meeting.

Conner, J., \& Ulrich, D. (1996). Human Resource Roles: Creating value, not rhetoric. HR. Human Resource Planning: Tempe, 19(3), 38.

Datta, D. K. (1991). Organizational Fit and Acquisition Performance Effects of Post-Acquisition Integration. Strategic Management Journal, 12(4), 281-297. https://doi.org/10.1002/smj.4250120404

Golden, B. R. (1992). SBU Strategy and Performance: The Moderating Effects of the Corporate-SBU Relationship. Strategic Management Journal, 13(2), 145-158. https://doi.org/10.1002/smj.4250130206

Hair, J. F., Black, W. C., Babin, B. J., Anderson, R. E., \& Tatham, R. L. (2006). 
Multivariate Data Analysis, $6^{\text {th }}$ Ed, Pearson Prentice Hall, Upper Saddle River, N. J.

Harold, K. (2003). Project Management: A Systems Approach to Planning, Scheduling and Controlling; Blackwell publishing.

Kim, H., \& Sung, C. K. (2011). Strategic HR Functions and Firm Performance: The Moderating Effects of High-Involvement Work Practice. Asia Pacific Journal of Management, 30(1), 91-113. https://doi.org/10.1007/s10490-011-9264-6

Kovach, K., Hughs, A., Fagan, P., \& Maggitti, P. (2002). Administrative and Strategic Advantages of HRIS. Employment Relations Today, 6. https://doi.org/10.1002/ert.10039

Krejcie, R.V., \& Morgan, D. W. (1970). Determining Sample Size for Research Activity. Educational and Phychological Measurement, 30, 607-610. https://doi.org/10.1177/001316447003000308

Lahteenmaki, S., Storey, J., \& Vanhala, S. (1988). HRM and Company Performance: The Use of Measurement and the Influence of Economic Cycles. Human Resource Management Journal, 8(2), 51-65. https://doi.org/10.1111/j.1748-8583.1998.tb00166.x

Lawler, E. E., \& Mohrman, A. M. (2003). Creating a strategic human resource organization: An assessment of trends and new directions. Stanford, CA: Stanford University Press.

Lee, F., Lee, T., \& Wu, W. (2010). The Relationship between Human Resource Management Practices, Business Strategy and Firm Performance: Evidence from Steel Industry in Taiwan; The International Journal of Human Resource Management, 21(9), 1351-1372. https://doi.org/10.1080/09585192.2010.488428

Levenson, A. (2005). Do Competencies Drive Organizational Performance? Can They? Evidence and Implications for Professional and HR Competencies. Center for Effective Organizations Working Paper. University of Southern California.

Levenson, A., Van der Stede, W., \& Cohen, S. (2005). Measuring the Relationship Between Managerial Competencies and Performance. Center for Effective Organizations Working Paper. University of Southern California.

Liu, H., Fu, Y., Wang, X., \& Fang, Y. (2014, June). Empirical Analysis of the Relationship between HR Professionals' Competency and Enterprise Performance. In 2014 International Conference on Management Science and Management Innovation (MSMI 2014). Atlantis Press. https://doi.org/10.2991/msmi-14.2014.96

Long, C. S., \& Wan, K. W. I. (2008). Understanding the Relationship of HR Competencies and Roles of Malaysian Human Resource Professionals. European Journal of Social Sciences, 7(1), 88-103.

Losey, M. (1999). Mastering the Competencies of HR Management. Human Resource Management, $38(2)$, 99-103. https://doi.org/10.1002/(SICI)1099-050X(199922)38:2<99::AID-HRM3>3.0.CO;2-T

Martins, L. P. (2007). A Holistic Framework for the Strategic Management of First Tier 
Managers.

Management

Decision,

$45(3)$

616-641.

https://doi.org/10.1108/00251740710745151

Mugavin, B. (2012). Project Management for Human Resources Professionals. FlashpointHR. Retrieved June 19, 2013, from World Wide Web: http://www.flashpointHR.com/pdf/articles/C4/0C37EB5.asp?Type=51 andCategory=1357.

Mukherjee, A. (2001). HR Transformation - Can Technology Help? Available at: www.humanlinks.com/manres/articles/hr transformation.htm.

Paauwe, J., \& Boselie, P. (2005). Best Practices in spite of Performance: Just a Matter of Imitation? International Journal of Human Resource Management, 16(6), 987-1003. https://doi.org/10.1080/09585190500120798

Paschke, J. (2009). Adaptive IT Capability and its Impact on the Competitiveness of Firms: A Dynamic Capability Perspective. PhD Thesis. School of Business Information Technology Business College RMIT University.

Pietersen, F. L., \& Englebrecht, A. S. (2005). The Strategic Partnership Role of Senior Human Resource Managers in South African organizations. Management Dynamics, 14(4), 47-58.

Ramlall, S. J. (2006). Identifying and Understanding HR Competencies and their Relationship to Organizational Practices. Applied HRM Research, 11(1), 27-38.

Richard, P., Devinney, T., Yip, G., \& Johnson, G. (2009). Measuring Organizational Performance: Towards Methodological Best Practice, Journal of Management, 35(3), 718-804. https://doi.org/10.1177/0149206308330560

Russell, C. J. (2001). A Longitudinal Study of Top-Level Executive Performance. Journal Applied Psychology, 86(4), 560-573. https://doi.org/10.1037/0021-9010.86.4.560

Scott, B. (2008). How to Become an Internal Consultant. Personnel Today. Retrieved 17 April, 2013 from World Wide Web: http://www.humanresourcemagazine.com.au/articles/B5/0C53EB5.asp?Type $=61$ andCategory $=1524$

Sekaran, U. (2003). Research Method for Business: A Skilled Building Approach (4 ${ }^{\text {th }}$ Ed.). 605 John Wiley \& Sons Inc. Third Avenue: New York.

Selmer, J., \& Chiu, R. (2004). Required Human Resource Competencies in the Future: A Framework for Developing HR Executives in Hong Kong. Journal of World Business, 39(4), 324-336. https://doi.org/10.1016/j.jwb.2004.08.001

Som, A. (2008). Innovative Human Resource Management and Corporate Performance in the context of Economic Liberalization in India, The International Journal of Human Resource Management, 19(7), 1278-1297. https://doi.org/10.1080/09585190802110075

Ulrich, D. (1997). Human Resource Champions: The next Agenda for Adding Value and Delivering Results. Harvard Business School Press. Retrieved May 17, 2013, from World 


\section{Macrothink \\ International Journal of Human Resource Studies \\ ISSN 2162-3058 2018, Vol. 8, No. 1}

Wide Web: www.gowerpub.com/pdf/HR Business Partner Ch1.pdf

Ulrich, D., \& Brockbank, W. (2001). Roles and Competencies of HR Professionals. Organization, People and HR: The General Manager Agenda. Retrieved August 5, 2013, from http://webuser.bus.edu/Programs/hrcs/res OrgPeople.htm.

Ulrich, D., \& Brockbank, W. (2005). The HR Value Proposition. Harvard Business School Press, Boston, MA.

Ulrich, D., Brockbank, W., Johnson, D., \& Younger, J. (2007). Human Resource Competencies: Responding to Increased Expectations. Employment Relations Today. (Wiley), 34(3), 1-12. https://doi.org/10.1002/ert.20159

Ulrich, D., Brockbank, W., Johnson, D., Sandholtz, K., \& Younger, J. (2008). HR Competencies: Master at the Intersection of People and Business, The RBL Institute, The Society for HRM.

Ulrich, D., Brockbank, W., Younger, J., \& Ulrich, M. (2012), HR Talent and the New HR $\begin{array}{llll}\text { Competencies, } \quad \text { Strategic } \quad H R \quad \text { Review, } & \text { 11(4), }\end{array}$ https://doi.org/10.1108/14754391211234940

Wright, P. M., Snell, S. A., \& Dyer, L. (2005). New Models of Strategic HRM in a Global Context, International Journal of Human Resource Management, 16(6), 875-881. https://doi.org/10.1080/09585190500120814

\section{Copyright Disclaimer}

Copyright for this article is retained by the author(s), with first publication rights granted to the journal.

This is an open-access article distributed under the terms and conditions of the Creative Commons Attribution license (http://creativecommons.org/licenses/by/4.0/). 